\title{
Effect of Milling Time on Pore Size and Distribution of Ti-Nb-Zr Biomaterials with Space Holder Consolidated by Spark Plasma Sintering
}

\author{
Dong-Gun Kim, Kee-Do Woo ${ }^{\dagger}$, Dong-Soo Kang and Tack Lee \\ Division of Advanced Materials Engineering, Research Center of Advanced Materials Development(RCAMD), \\ Chonbuk National University, Jeonbuk 561-756, Korea
}

(Received January 14, 2014 : Received in revised form February 20, 2014 : Accepted February 20, 2014)

\begin{abstract}
Titanium and its alloys are useful for implant materials. In this study, porous Ti-Nb-Zr biomaterials were successfully synthesized by powder metallurgy using a $\mathrm{NH}_{4} \mathrm{HCO}_{3}$ as space holder and $\mathrm{TiH}_{2}$ as foaming agent. Consolidation of powder was accomplished by spark plasma sintering process(SPS) at $850{ }^{\circ} \mathrm{C}$ under $30 \mathrm{MPa}$ condition. The effect of high energy milling time on pore size and distribution in Ti-Nb- $\mathrm{Zr}$ alloys with space holder( $\left(\mathrm{NH}_{4} \mathrm{HCO}_{3}\right)$ was investigated by optical microscope(OM), scanning electron microscope(SEM) \& energy dispersive spectroscopy(EDS) and X-ray diffraction(XRD). Microstructure observation revealed that, a lot of pores were uniformly distributed in the Ti-Nb-Zr alloys as size of about 30$100 \mu \mathrm{m}$ using mixed powder and milled powders. In addition, the pore ratio was found to be about $5-20 \%$ by image analysis, using an image analyzer(Image Pro Plus). Furthermore, the physical properties of specimens were improved with increasing milling time as results of hardness, relative density, compressive strength and Young's modulus. Particularly Young's modulus of the sintered alloy using $4 \mathrm{~h}$ milled powder reached $52 \mathrm{GPa}$ which is similar to bone elastic modulus.
\end{abstract}

Key words biomaterial, Ti alloy, space holder, spark plasma sintering, high energy mechanical milling.

\section{Introduction}

Ti and Ti-based alloys are widely used as biomaterials due to the combination of its outstanding characteristics such as high strength, low density(high specific strength), high immunity to corrosion, complete inertness to body environment, enhanced biocompatibility, low modulus and high capacity to join with bone and other tissues. ${ }^{1,2)}$ Nowadays, pure titanium, Ti-6Al-4V ELI(extra low interstitial) alloys have been widely used as dental and orthopedic implants. ${ }^{3,4)}$ In addition, its elastic modulus is $50 \%$ less than that in Co-Cr implants. So pure titanium, Ti-6Al-4V ELI alloys would help to reduce a stress shielding effect. However Ti-6Al-4V ELI alloys has been considered because of the toxic elements to health, such as $\mathrm{Al}$ and $\mathrm{V}^{5}$ ) There are some problems of the solid implant materials in orthopedic surgery, such as lack of osteointegration capacity and inadequate mechanical properties of Young's modulus. The mismatch of Young's modulus between the bone (2-20GPa) and the metallic implants of pure Ti and Ti-6Al-4V ELI alloy (100-120 $\mathrm{GPa}$ ) is about $100 \mathrm{GPa}^{6}{ }^{6}$ Therefore, it is important for biometallic materials to have low Young's modulus. Porous metallic biomaterials are one of the methods to reduce the Young's modulus.

There is a limit to the addition of alloying elements in a way of reducing the Young's modulus.

In this study, to solve these problems(toxic elements and high Young's modulus) was to fabricate a porous Ti$\mathrm{Nb}-\mathrm{Zr}$ alloy, which is known as low Young's modulus alloy due to $\beta$-Ti phase and good biocompatibility due to non toxic elements, ${ }^{7)}$ using space holder method. Space holder method was cost effective process. Also it controlled pore size distribution and pore shape. During sintering, space holder was removed after mixing a metal powder and space holder. And then this method fabricated porous material by sintered metal powder to keep pore size and shape. It kind of $\mathrm{NaF}, \mathrm{NaCl}, \mathrm{NH}_{4} \mathrm{HCO}_{3}$, etc and

\footnotetext{
${ }^{\dagger}$ Corresponding author

E-Mail : kdwoo@jbnu.ac.kr (K.-D. Woo, Chonbuk Nat'l Univ.)
}

(C) Materials Research Society of Korea, All rights reserved.

This is an Open-Access article distributed under the terms of the Creative Commons Attribution Non-Commercial License (http://creativecommons.org/licenses/by-nc/3.0) which permits unrestricted non-commercial use, distribution, and reproduction in any medium, provided the original work is properly cited. 
porosity was about $60 \sim 80 \%{ }^{8)}$

In this study, to make a porous Ti-Nb-Zr alloy were used to $\mathrm{Ti}$ powder, $\mathrm{Nb}$ powder, $\mathrm{Zr}$ powder, $\mathrm{NH}_{4} \mathrm{HCO}_{3}$ as space holder and $\mathrm{TiH}_{2}$ as foaming agent. And then these mixing and milling powders were sintered by SPS.

\section{Experimental procedure}

The raw powder was added Ti- $13 \mathrm{wt} \% \mathrm{Nb}-13 \mathrm{wt} \% \mathrm{Zr}-$ $10 \mathrm{wt} \% \mathrm{NH}_{4} \mathrm{HCO}_{3}-2 \mathrm{wt} \% \mathrm{TiH}_{2}$, in which of high purity $\mathrm{Ti}$ $(99.9 \%, 100 \mu \mathrm{m}), \mathrm{Nb}(99.9 \%, 120 \mu \mathrm{m}), \mathrm{Zr}(99.8 \%, 100$ $\mu \mathrm{m}), \mathrm{TiH}_{2}(99 \%, 10 \mu \mathrm{m})$ and pure $\mathrm{NH}_{4} \mathrm{HCO}_{3}$ powder $(99.9 \% 120 \sim 200 \mu \mathrm{m})$ were used. Ti- $13 \mathrm{wt} \% \mathrm{Nb}-13 \mathrm{wt} \% \mathrm{Zr}$ alloy powders were mixed for $24 \mathrm{~h}$ using a low energy mixing equipment with a $\mathrm{ZrO}_{2}$ ball to powder ratio of $7: 1$. The powders were milled using high energy mechanical milling(SPEX 8000 mill/mixer) with $\mathrm{ZrO}_{2}$ balls (weight ratio of $\mathrm{ZrO}_{2}$ ball to powder was 4:1) in hardened steel vial. Isopropyl alcohol was used as process control agent(PCA) during the HEMM. The powders were milled in $\mathrm{Ar}$ atmosphere for different times( $4 \mathrm{~h}, 8 \mathrm{~h}$ and $12 \mathrm{~h})$. And then Ti- $13 \mathrm{wt} \% \mathrm{Nb}-\mathrm{wt} \% \mathrm{Zr}$ alloy powders added 10 $\mathrm{wt} \% \mathrm{NH}_{4} \mathrm{HCO}_{3}$ and $2 \mathrm{wt} \% \mathrm{TiH}_{2}$ were mixed for $1 \mathrm{~h}$ using mixer. The mixed and milled powders were placed in a $10 \mathrm{~mm}$-diameter cylindrical graphite die of the SPS equipment. ${ }^{9)}$ The chamber was evacuated down to $10^{-3}$ torr and a uniaxial pressure of $30 \mathrm{MPa}$ was applied. The mixed and milled powders were sintered at $850{ }^{\circ} \mathrm{C}$ and instantly cooled without holding time in chamber at $\mathrm{Ar}$ atmosphere due to rapid cooling. Temperature was measured using a thermocouple on the surface of the graphite die.

The phases of the sintered Ti-Nb-Zr- $\mathrm{NH}_{4} \mathrm{HCO}_{3}-\mathrm{TiH}_{2}$ biomaterials and as mixed and as milled powders were investigated using $\mathrm{X}$-ray diffraction(XRD) with $\mathrm{Cu}-\mathrm{K} \alpha$ radiation within the range of $20-80^{\circ}$. The pore size and distribution were observed by scanning electron microscope(JMS-6400 : SEM) and the pore size and ratio was measured by image analyzer(Image Pro Plus). The density of the sintered Ti-Nb-Zr biomaterials was calculated by Archimedes' method. The hardness of the sintered biomaterials was measured using Rockwell hardness tester (Load: $60 \mathrm{~kg}$ ).

\section{Results and discussion}

Fig. 1 shows SEM micrographs of the mixed and milled Ti- $13 \mathrm{wt} \% \mathrm{Nb}-13 \mathrm{wt} \% \mathrm{Zr}$ alloy powders with $10 \mathrm{wt} \%$ $\mathrm{NH}_{4} \mathrm{HCO}_{3}-2 \mathrm{wt} \% \mathrm{TiH}_{2}$ powders. The particle sizes of the composite powders decreased from $20 \sim 40 \mu \mathrm{m}$ (Fig. 1b, 1c) to less than $5 \sim 20 \mu \mathrm{m}$ (Fig. 1d). Fine particles are Ti based alloys and big particles are space holder particles. The size of Ti based alloy particles is ultra fine. By XRD analysis, the size of high energy mechanical milled particle for is $4 \sim 12 \mathrm{~h}$ is $200 \mathrm{~nm}$ to $5 \mu \mathrm{m}$. Particle size of Ti-Nb-Zr
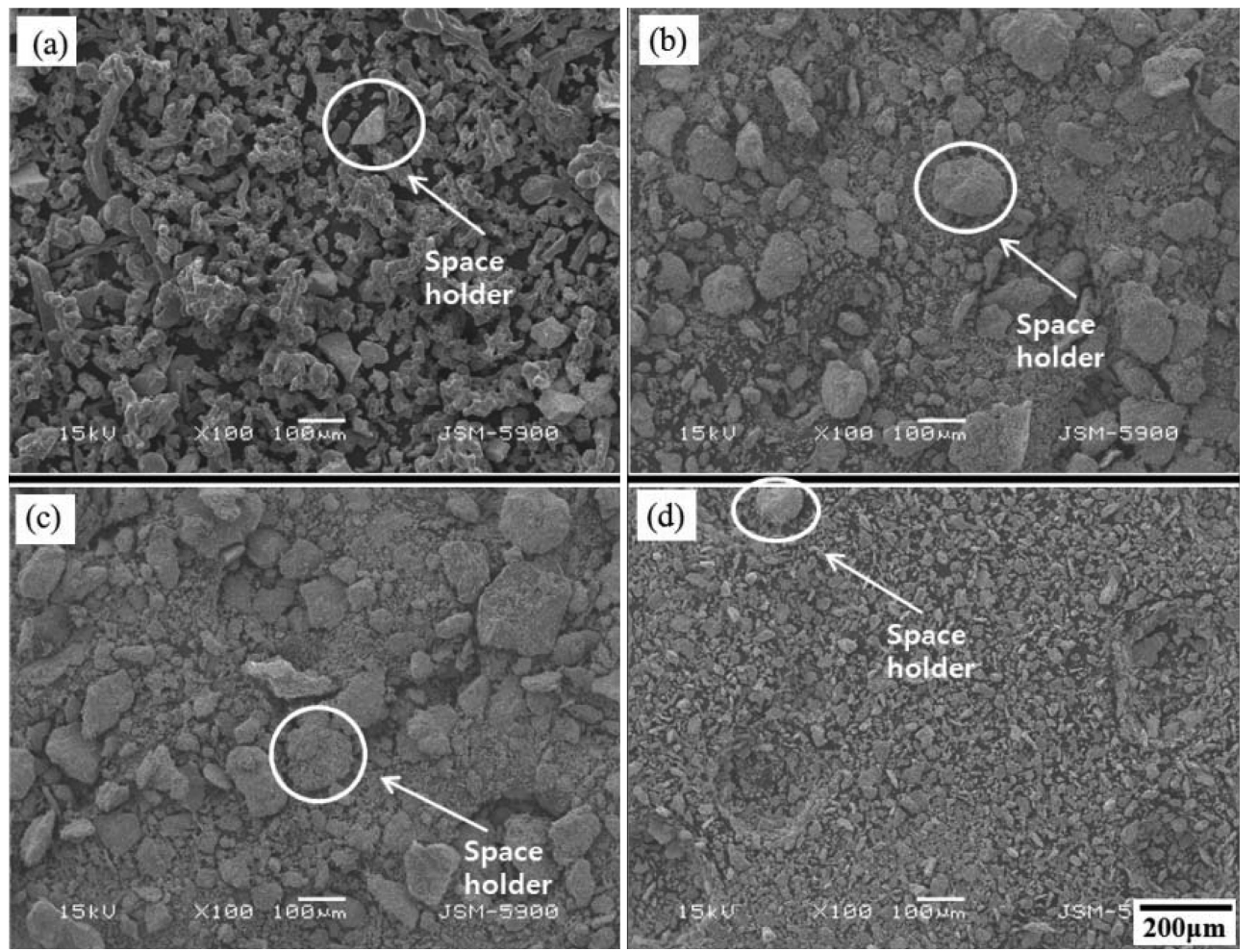

Fig. 1. SEM micrographs of the Ti-13\% Nb-13\% Zr alloy powders mixed for $24 \mathrm{~h}$ or milled for $4-12 \mathrm{~h}$ and followed by mixed with $10 \% \mathrm{NH}_{4} \mathrm{HCO}_{3}-2 \% \mathrm{TiH}_{2}$ for $1 \mathrm{~h}$ using mixer; (a) $24 \mathrm{~h}$ mixed, (b) $4 \mathrm{~h}$ milled, (c) $8 \mathrm{~h}$ milled and (d) $12 \mathrm{~h}$ milled Ti-13\% Nb-13\%Zr powder. 


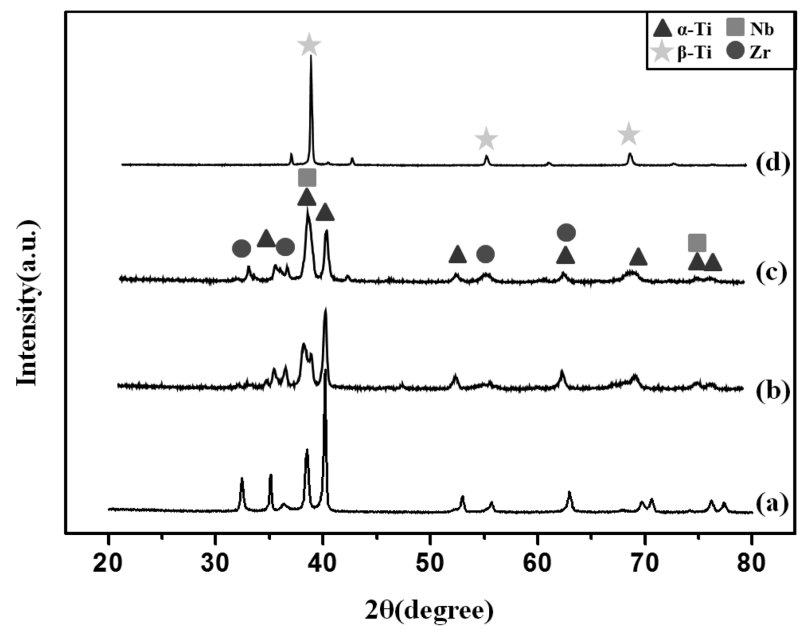

Fig. 2. XRD patterns of the sintered Ti-13\%Nb-13\%Zr alloys using mixed powder for $24 \mathrm{~h}$ or milled powder for $4-12 \mathrm{~h}$ and followed by mixed with $10 \% \mathrm{NH}_{4} \mathrm{HCO}_{3}-2 \% \mathrm{TiH}_{2}$ for $1 \mathrm{~h}$ using mixer; (a) $24 \mathrm{~h}$ mixed, (b) $4 \mathrm{~h}$ milled, (c) $8 \mathrm{~h}$ milled and (d) $12 \mathrm{~h}$ milled.

powder, which is mixed with very high melting point elements, is very important to consolidate sound specimen by sintering. And the shape of the high energy milled powders changed from irregular shape to round shape. Consequently, the morphology and size of Ti-13\% Nb$13 \% \mathrm{Zr}$ alloy powders was more regularly changed with increasing milling time. The shapes of space holder $\left(\mathrm{NH}_{4} \mathrm{HCO}_{3}\right)$ were kept as round shape because the Ti$13 \mathrm{wt} \% \mathrm{Nb}-13 \mathrm{wt} \% \mathrm{Zr}$ powder with $10 \mathrm{wt} \% \mathrm{NH}_{4} \mathrm{HCO}_{3}-2 \mathrm{wt} \%$ $\mathrm{TiH}_{2}$ composite powders didn't milled due to keep size and shape of the space holder.

Fig. 2 shows the XRD analysis results of the sintered Ti-13\% Nb-13\%Zr alloys with $10 \mathrm{wt} \% \mathrm{NH}_{4} \mathrm{HCO}_{3}-2 \mathrm{wt} \% \mathrm{TiH}_{2}$ using mixed and milled Ti- $13 \mathrm{wt} \% \mathrm{Nb}-13 \mathrm{wt} \% \mathrm{Zr}$ alloy powders. The XRD results show that $\alpha$-Ti phase was remained in all sintered specimens except the Ti- $13 \mathrm{wt} \% \mathrm{Nb}$ -
$13 \mathrm{wt} \% \mathrm{Zr}$ alloys sintered by SPS using $12 \mathrm{~h}$ high energy milled powder, but its diffraction intensity was relatively decreased with increasing milling time. Furthermore, $\beta$ Ti phase was formed caused by transformation of $\alpha-\mathrm{Ti}$ phase in $12 \mathrm{~h}$ milled specimen. It might be occurred due to a role of $\mathrm{Nb}$ as a $\beta$ phase stabilizing alloying. And other reasons are increase of defect density such as dislocation and vacancy and increase of grain boundary energy due to high energy mechanical milling. These defects and ultra fine grains increased diffusion rate and decreased activation energy of deformation from $\alpha$-Ti phase to $\beta$-Ti phase. Other small peaks are due to oxide such as $\mathrm{TiO}_{2}$ formed during milling and sintering.

Ammonium hydrogen carbonate $\left(\mathrm{NH}_{4} \mathrm{HCO}_{3}\right)$ evaporates at below $200{ }^{\circ} \mathrm{C}$ as an ammonia, carbon dioxide and water by following reaction ${ }^{7}$;

$$
\mathrm{NH}_{4} \mathrm{HCO}_{3}=\mathrm{NH}_{3} \uparrow+\mathrm{CO}_{2} \uparrow+\mathrm{H}_{2} \mathrm{O} \uparrow
$$

For this reason, it could not find space holder in the sintered specimens.

Fig. 3 shows OM micrographs and area percent of pore and Fig. 4 shows SEM micrographs of the sintered Ti$13 \% \mathrm{Nb}-13 \% \mathrm{Zr}$ alloys with $10 \mathrm{wt} \% \mathrm{NH}_{4} \mathrm{HCO}_{3}-2 \mathrm{wt} \% \mathrm{TiH}_{2}$. From the result of image analysis using image analyzer (Image Pro Plus), the pore ratio of (a), (b), (c) and (d) was $21.74,10.42,8.36,5.6 \%$, respectively and decrease with increasing milling time. The pore shape is similar to initial shape of space holder appeared in 24h-mixed specimen (a). But the size of pores decreased up to $20 \sim 50 \mu \mathrm{m}$ in $12 \mathrm{~h}$ milled specimen (b) using ultra fine Ti- $13 \% \mathrm{Nb}-$ $13 \% \mathrm{Zr}$ milled powder with a pressure $(30 \mathrm{MPa})$ during sintering.

Fig. 5 shows elemental mapping results of the sintered Ti-13wt $\% \mathrm{Nb}-13 \mathrm{wt} \% \mathrm{Zr}$ alloys with $10 \mathrm{wt} \% \mathrm{NH}_{4} \mathrm{HCO}_{3}-2 \mathrm{wt} \%$

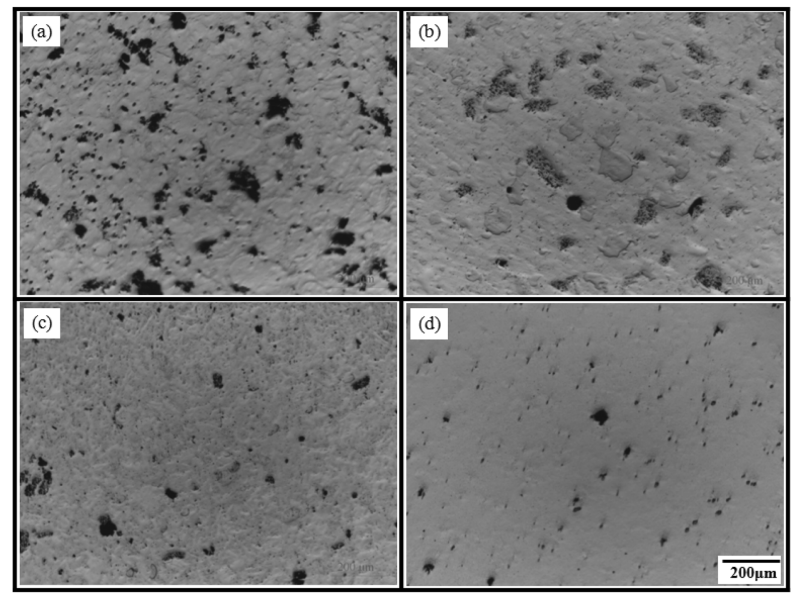

\begin{tabular}{|c|c|}
\hline Milling time & $\begin{array}{c}\text { Pore } \\
\text { ratio( \% ) }\end{array}$ \\
\hline 24h mixed & 21.74 \\
\hline $4 \mathrm{~h}$ milled & 10.42 \\
\hline $8 \mathrm{~h}$ milled & 8.36 \\
\hline $12 \mathrm{~h}$ milled & 5.6 \\
\hline
\end{tabular}

Fig. 3. OM micrographs and area percent of pores of the sintered Ti-13\%Nb-13\% $\mathrm{Zr}$ alloy using mixed powder for $24 \mathrm{~h}$ or milled powder for $4-12 \mathrm{~h}$ and followed by mixed with $10 \% \mathrm{NH}_{4} \mathrm{HCO}_{3}-2 \% \mathrm{TiH}_{2}$ for $1 \mathrm{~h}$ using mixer; (a) $24 \mathrm{~h}$ mixed, (b) $4 \mathrm{~h}$ milled, (c) $8 \mathrm{~h}$ milled and (d) $12 \mathrm{~h}$ milled. 

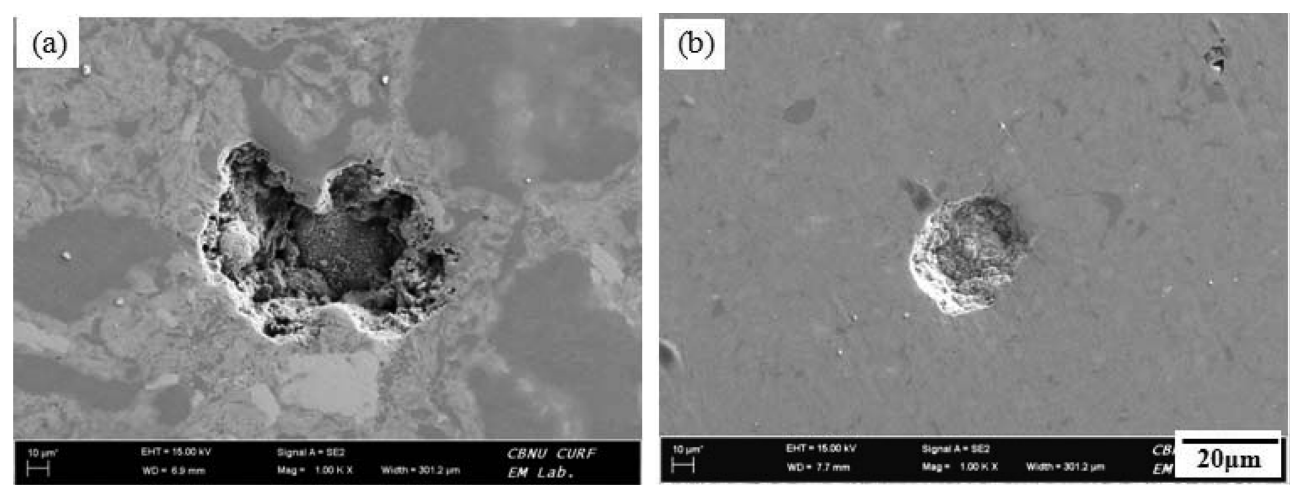

Fig. 4. SEM micrographs of the sintered Ti-13\%Nb-13\%Zr alloy using mixed powder for $24 \mathrm{~h}$ or milled powder for $12 \mathrm{~h}$ and followed by mixed with $10 \% \mathrm{NH}_{4} \mathrm{HCO}_{3}-2 \% \mathrm{TiH}_{2}$ for $1 \mathrm{~h}$ using mixer. (a) $24 \mathrm{~h}$ mixed, (b) $12 \mathrm{~h}$ milled.

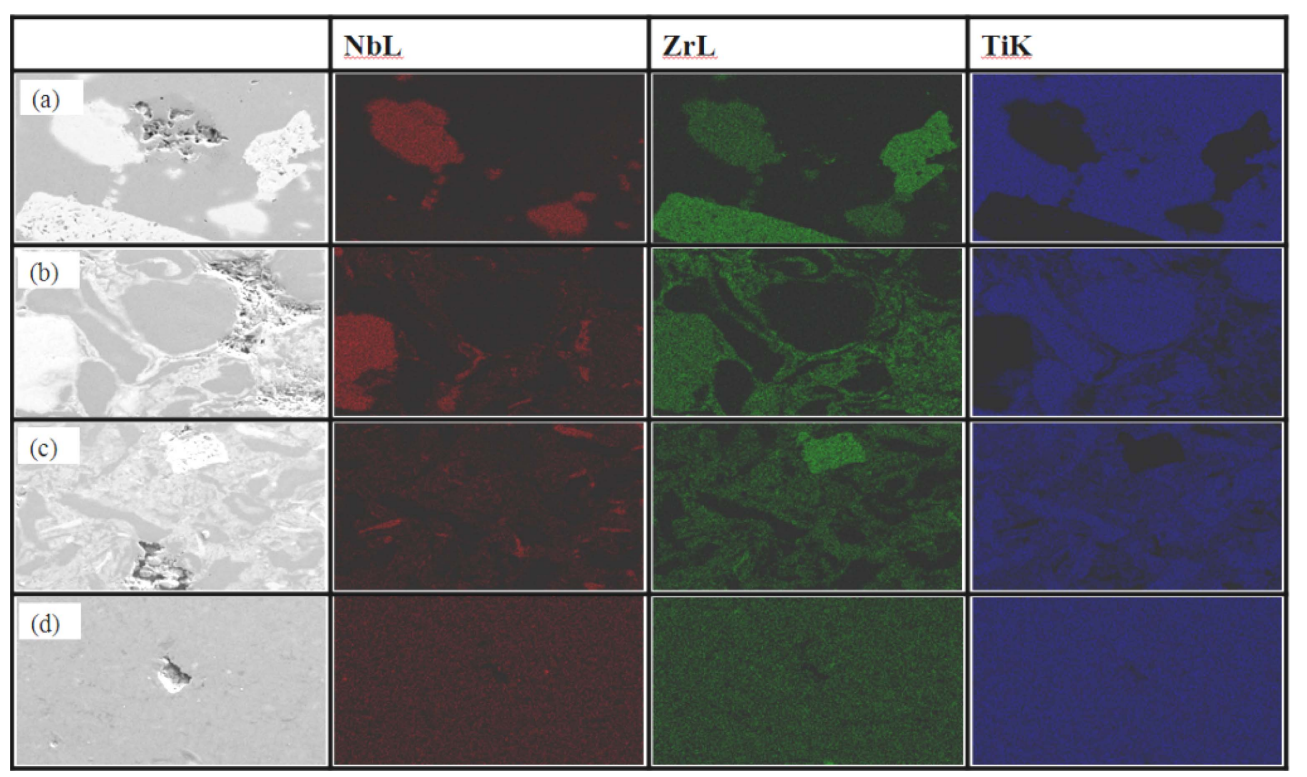

Fig. 5. Elemental mapping results of the sintered Ti-13\% Nb-13\%Zr alloys using mixed powder for $24 \mathrm{~h}$ or milled powder for $4-12 \mathrm{~h}$ and followed by mixed with $10 \% \mathrm{NH}_{4} \mathrm{HCO}_{3}-2 \% \mathrm{TiH}_{2}$ for $1 \mathrm{~h}$ using mixer; (a) $24 \mathrm{~h}$ mixed, (b) $4 \mathrm{~h}$ milled, (c) $8 \mathrm{~h}$ milled and (d) $12 \mathrm{~h}$ milled.

$\mathrm{TiH}_{2}$. In case of mixing for $24 \mathrm{~h}, \mathrm{Nb}$ and $\mathrm{Zr}$ rich phases(white region) were appeared in Ti matrix, and the distribution of each element was uniformly distributed

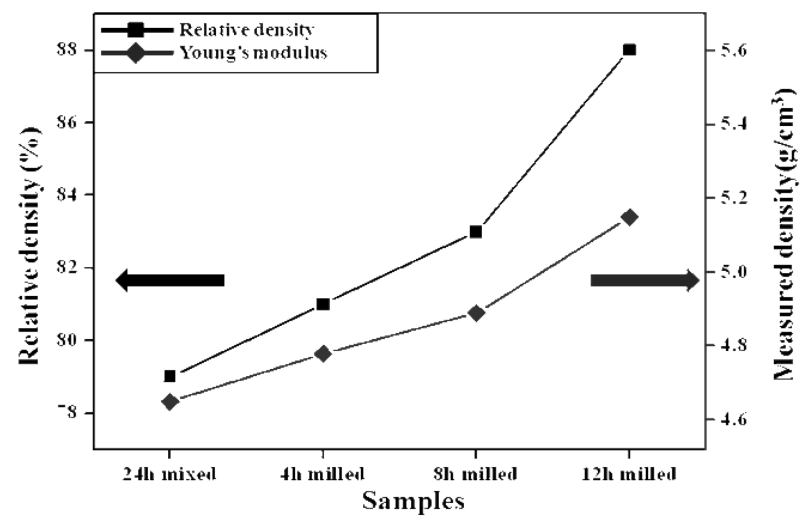

Fig. 6. The relative and measured density of the sintered Ti$13 \% \mathrm{Nb}-13 \% \mathrm{Zr}-\left(10 \% \mathrm{NH}_{4} \mathrm{HCO}_{3}-2 \% \mathrm{TiH}_{2}\right)$ composites. with increasing milling time. Because $\mathrm{Nb}$ and $\mathrm{Zr}$ elements were solid soluted in Ti matrix.

Fig. 6 shows the results of relative and measured density of the sintered $\mathrm{Ti}-13 \% \mathrm{Nb}-13 \% \mathrm{Zr}-\left(10 \mathrm{wt} \% \mathrm{NH}_{4} \mathrm{HCO}_{3}-\right.$ $2 \mathrm{wt} \% \mathrm{TiH}_{2}$ ) composites. With increase milling time, relative density was increased as a value of $79,81,83,88 \%$ respectively, and measured density was increased as a value of $4.65,4.78,4.89$ and $5.15 \mathrm{~g} / \mathrm{cm}^{3}$. This is because density depends on milling time.

Fig. 7 shows the hardness of the sintered $\mathrm{Ti}-13 \% \mathrm{Nb}-$ $13 \% \mathrm{Zr}$ alloys with $10 \% \mathrm{NH}_{4} \mathrm{HCO}_{3}-2 \% \mathrm{TiH}_{2}$. The hardness was increased with increase milling time from 107.2 to 125.6 for mixed powder and $12 \mathrm{~h}$ milled powder respectively. This is because grain size of sintered alloy using milled powder decreased with milling time.

Fig. 8 shows compressive strength and Young's modulus of the sintered $\mathrm{Ti}-13 \% \mathrm{Nb}-13 \% \mathrm{Zr}$ alloy using mixed and milled powder and followed by mixed with $10 \%$ 


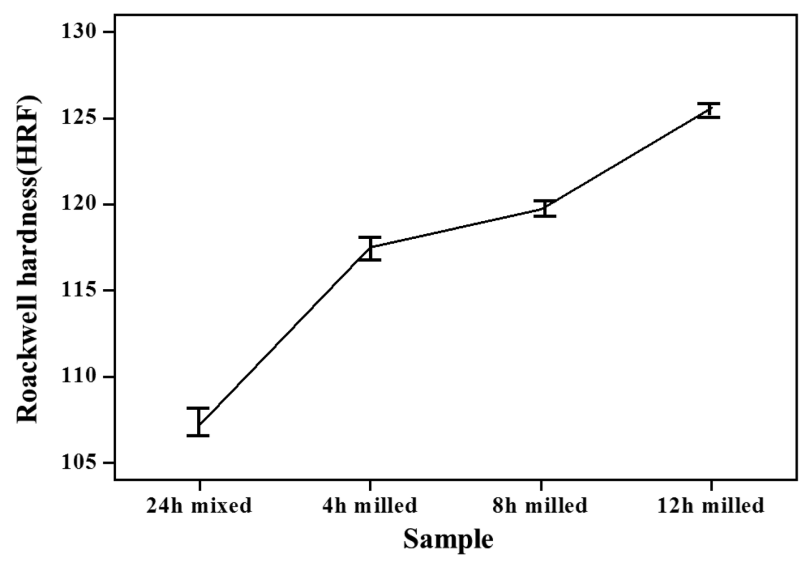

Fig. 7. The Rockwell hardness of the sintered Ti- $13 \% \mathrm{Nb}-13 \% \mathrm{Zr}$ alloys with $10 \% \mathrm{NH}_{4} \mathrm{HCO}_{3}-2 \% \mathrm{TiH}_{2}$ using mixed and milled powders.

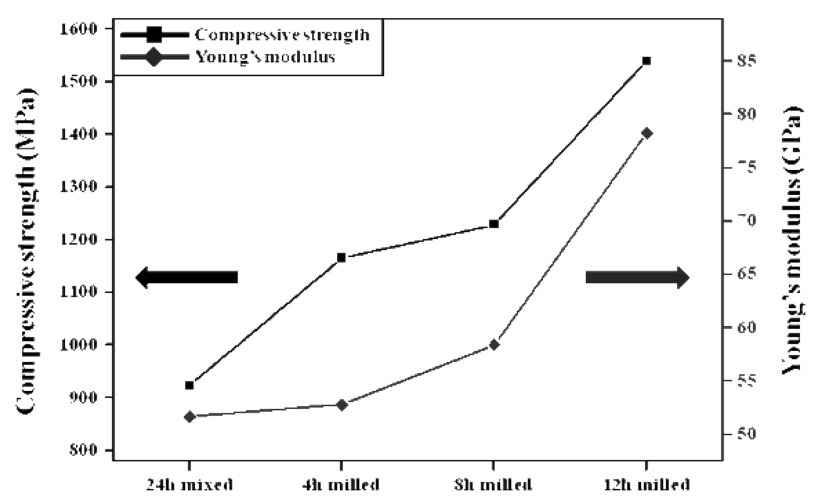

Fig. 8. Compressive strength and Young's modulus of the sintered Ti-13\% Nb-13\%Zr alloy using mixed and milled powder and followed by mixed with $10 \% \mathrm{NH}_{4} \mathrm{HCO}_{3}-2 \% \mathrm{TiH}_{2}$ for $1 \mathrm{~h}$ using mixer.

$\mathrm{NH}_{4} \mathrm{HCO}_{3}-2 \% \mathrm{TiH}_{2}$ for $1 \mathrm{~h}$ using mixer. With increase milling time, compressive strength was increased as value of 923, 1166, 1229, 1540MPa respectively, and Young's modulus was increased as a value of $51,52,58$ and $78 \mathrm{GPa}$.

This is because the mechanical property is affected by grain size and density of specimen. The size of $12 \mathrm{~h}$ milled powder can be obtained nano-size. This paper is intended to obtain an elastic modulus to be similar to bone elastic modulus, but it is obtained a higher elastic modulus than bone. Is a result of using the $10 \%$ space holder. Therefore adjusting the amount of space holder, it is expected that it is possible to obtain elastic modulus similar bone.

\section{Conclusions}

In this study, it examined the effects on the mechanical properties and pore characteristics of biomaterials by spark plasma sintering using space holder.

1) Having the low Young's modulus, porous $\mathrm{Ti}-\mathrm{Nb}-\mathrm{Zr}$ biomaterials with space holder $\left(\mathrm{NH}_{4} \mathrm{HCO}_{3}\right)$ and pore foaming agent $\left(\mathrm{TiH}_{2}\right)$ were successfully fabricated by SPS using high energy mechanical milled and mixed powders.

2) The sintered $\mathrm{Ti}-13 \% \mathrm{Nb}-13 \% \mathrm{Zr}$ alloys using $12 \mathrm{~h}$ milled powder showed ultrafine grain and addition elements such as $\mathrm{Nb}$ and $\mathrm{Zr}$ distributed uniformly.

3) $\beta$ - phase Ti- $13 \% \mathrm{Nb}-13 \% \mathrm{Zr}$ alloy can be fabricated by SPS at $850{ }^{\circ} \mathrm{C}$ using $12 \mathrm{~h}$ milled powder.

4) The pore ratio was decreased with increasing milling time. The size of pore of the sintered specimen using $12 \mathrm{~h}$ milled powder was decreased up to $20 \sim 50 \mu \mathrm{m}$ during sintering.

5) The density, hardness, compressive strength and Young's modulus was increased with milling time, because of grain size of sintered alloys were decreased with increasing milling time.

\section{Acknowledgements}

This research was conducted with financial support from the National Research Foundation(NRF) (No: 20131301000703) of Korea.

\section{References}

1. M. Long and H. J. Rack, Biomater., 19, 1621 (1998).

2. H. S. Kim, W. Y. Kim and S. H. Lim, Scr. Mater., 54, 887 (2006).

3. E. Takahashi, T. Sakurai, S. Watanabe, N. Masahashi, and S, Mater. Trans., 43, 2978 (2002).

4. L. M. Elias, S. G. Schneider, S. Schneider, H. M. Silva and F. Malvisi, Mater. Sci. Eng. A, 432, 108 (2006).

5. H. S. Kim, S. H. Lim, I. D. Yeo, W. Y. Kim, Mater. Sci. Eng. A, 449, 322 (2007).

6. Geetha M., Singh AK., Asokamani R. and Gogia AK., Progr. Mater. Sci., 54, 397 (2009).

7. L. M. Elias, S. G. Schneider, H. M. Silva and F. Malvisi, Mater. Sci. Eng., A 432, 108 (2006).

8. Nouri, Alireza, Hodgson, Peter D., and Wen, Cui'e, in Biomimetics learning from nature, ed. Mukherjee, Amitava (InTech, Rijek, Croatia, 2010) p.415.

9. K. D. Woo, S. M. Kim, D. G. Kim, D. Y. Kim and D. S. Kang, Kor. J. Mater. Res., 23, 135 (2013). 